\title{
Characterization of anti-EBA175RIII-V in asymptomatic adults and children living in communities in the Greater Accra Region of Ghana with varying malaria transmission intensities
}

\author{
L. E. Amoah" ${ }^{1 *}$, H. B. Abagna ${ }^{1}$, K. Akyea-Mensah' ${ }^{1}$, A. C. Lo ${ }^{1,2}$, K. A. Kusi ${ }^{1}$ and B. A. Gyan ${ }^{1}$
}

\begin{abstract}
Background: Antibodies against Region III-V of the erythrocyte binding antigen (EBA) 175 (EBA175RIII-V) have been suggested to provide protection from malaria in a natural infection. However, the quality and quantity of naturally induced antibodies to EBA175RIII-V has not been fully characterized in different cohorts of Ghanaians. This study sought to determine the characteristics of antibodies against EBA175RIII-V in asymptomatic adults and children living in two communities of varying $P$. falciparum parasite prevalence in southern Ghana.

Methods: Microscopic evaluation of thick and thin blood smears was used to identify asymptomatic Plasmodium falciparum carriage and indirect enzyme linked immunosorbent (ELISA) used to assess antibody concentrations and avidity.

Results: Parasite carriage estimated by microscopy in Obom was 35.6\% as opposed to 3.5\% in Asutsuare. Levels of IgG, IgG1, IgG2, IgG3 and IgG4 against EBA175RIII-V in the participants from Obom were significantly higher $(P<0.05$, Dunn's Multiple Comparison test) than those in Asutsuare. However the relative avidity of lgG antibodies against EBA175RIII-V was significantly higher ( $P<0.0001$, Mann Whitney test) in Asutsuare than in Obom.
\end{abstract}

Conclusions: People living in communities with limited exposure to $P$. falciparum parasites have low quantities of high avidity antibodies against EBA175RIII-V whilst people living in communities with high exposure to the parasites have high quantities of age-dependent but low avidity antibodies against EBA175RIII-V.

\section{Introduction}

The asexual stages of Plasmodium falciparum (P. falciparum) are partly responsible for the pathology associated with malaria and subsequently are the focus of malaria treatment regimens as well as the focus of malaria vaccine research. The merozoite is the only extracellular stage of the parasites erythrocytic life-cycle, making merozoite surface antigens promising malaria vaccine candidates. One such candidate is the erythrocyte binding antigen (EBA) 175 (EBA 175, Pf3D7_0731500), PfEBA-175 has been shown to play a

\footnotetext{
* Correspondence: lamoah@noguchi.ug.edu.gh

${ }^{1}$ Noguchi Memorial Institute for Medical Research, University of Ghana, Accra, Ghana

Full list of author information is available at the end of the article
}

key role during the fast cascade of interactions between the parasite and host molecules before the merozoite completely invades the erythrocyte by binding to sialic acid residues on glycophorin A on the red blood cell during merozoite invasion [1]. Of the 6 extracellular domains of EBA175, region 2 (RII), which comprises of two cysteine rich domains F1 and F2 [2] as well as RIII-V, which comprises of the dimorphic region 3 (RIII) as well as the highly conserved regions 4 (RIV) and 5 (RV) [2] have been implicated as vaccine candidate antigens.

Antibodies induced against diverse antigenic components of the erythrocytic parasite are important mediators of anti-disease immunity [3]. Some known functions of antibodies induced against the asexual parasite 
include preventing merozoites from invading new erythrocytes (inhibition of invasion), preventing cytoadherence of infected erythrocytes to endothelial cells as well as interfering with the normal function of monocytes and macrophages $[4,5]$. Targeting the merozoite before they invade erythrocytes can serve as a means to truncate the infection. The ability of antibodies against the merozoite to prevent erythrocyte invasion has been demonstrated through in vivo human passive transfer assays $[6,7]$ and in vitro erythrocyte invasion inhibition assays [8] several years ago. Antibodies specific for EBA175 RIII-V have been shown to be associated with protection from malaria in symptomatic cases [9]. Also, Healer et al., [10] in immunization studies have shown that antibodies induced by a recombinant RIII-V inhibit merozoites invasion.

Repeated exposure to malaria parasites has been suggested as a necessary requirement for the maintenance of anti-parasite immunity as it has been demonstrated in a number of studies that antibodies against merozoite antigens are relatively short-lived in the absence of a new infections [11-14]. This has been confirmed in some community studies where people with current infections had higher merozoite antibody levels than those without [15-17]. However, a few studies including one by Wipasa et al., noticed that both antibody and memory $\mathrm{B}$ cell responses to malaria antigens remained steady over long periods in the absence of an infection [18]. Some studies have suggested that merozoite antibody levels show a direct correlation with malaria transmission intensity in malaria endemic settings and are higher in high transmission settings $[19,20]$.

The cytophilic immunoglobulins, IgG1 and IgG3 have been associated with parasite repression directly, or opsonization indirectly [21]. IgG1 and IgG3 antibodies to merozoite antigens generally have short half-lives [12]. The half-lives of IgG subclass responses against EBA175 are generally short lived, however, the half-lives of IgG1 and IgG3 have been noted to be longer lived and more prevalent than those of IgG2 and IgG4 [21, 22]. IgG1 and IgG3 responses against EBA175 have also been associated with lower parasitaemia in a high transmission setting [21] as well as a seasonal transmission setting of Papua New Guinea [23].

The process of antibody selection that occurs during humoral immune response maturation, results in the production of antibodies with increased avidity [24, 25]. Antibody properties, including high avidity, have been suggested to key determinants of protective immunity against malaria [26-28]. High Avidity to whole schizont extract as well as to a number of specific $P$. falciparum antigens, have been shown to correlate with protection from malaria [29-31]. The avidity of antibodies against MSP1 has been observed to increase after a recent $P$. falciparum infection [29], however some reports have implicated reduced antibody affinity maturation and antibody avidity to a recent malaria infection [32] and excessive stimulation of $\mathrm{B}$ cells in high parasite prevalence settings [33]. The avidity of antibodies to $P$. falciparum antigens has been found to be lower in areas of high malaria transmission intensity than in areas with lower transmission [34].

This study sought to determine differences in the characteristics of antibody responses to EBA175RIII-V in adults and children living in high and low malaria parasite prevalence settings.

\section{Methods}

\section{Ethical consideration}

Ethical approval for the study (\#089/14-15) was obtained from the Institutional Review Board of the Noguchi Memorial Institute for Medical Research. Written informed consent, assent and parental consent were obtained for all participants recruited into the study.

\section{Study site and population}

The cross-sectional study conducted in June 2016, recruited adults and children aged between 2 and 75 years from two semi-rural communities, Obom and Asutsuare, both within the Greater Accra Region of Ghana as part of a large study which aims to identify a number of factors that influence asymptomatic $P$. falciparum carriage in high and low malaria transmission settings in Ghana. This study only recruited people in the two communities who did not exhibit any sign or symptom of clinical malaria and provided written informed consent for either themself or a dependent. Obom is a high P. falciparum prevalence community in the Ga South Municipality and Asutsuare is a low P. falciparum prevalence community, with noted low malaria transmission [35] in the Shai Osudoku District (Fig. 1). The major malaria season in the Greater Accra Region is from June to August, with a peak in July [36].

\section{Sample collection and processing}

After obtaining written informed consent, $5 \mathrm{ml}$ of venous blood was collected from each participant into acid citrate dextrose (ACD) vacutainer tubes. A drop of the whole blood was used to prepare thick and thin blood smears and the rest was separated into plasma and packed cells after centrifugation. The plasma was immediately stored at $-20^{\circ} \mathrm{C}$. Demographic data from the participants including ownership of insecticide treated bed nets (ITN) was also captured.

\section{Microscopic identification of $P$. falciparum parasites}

Thin and thick blood smears were processed using a method described by the WHO [37]. Briefly thin blood 


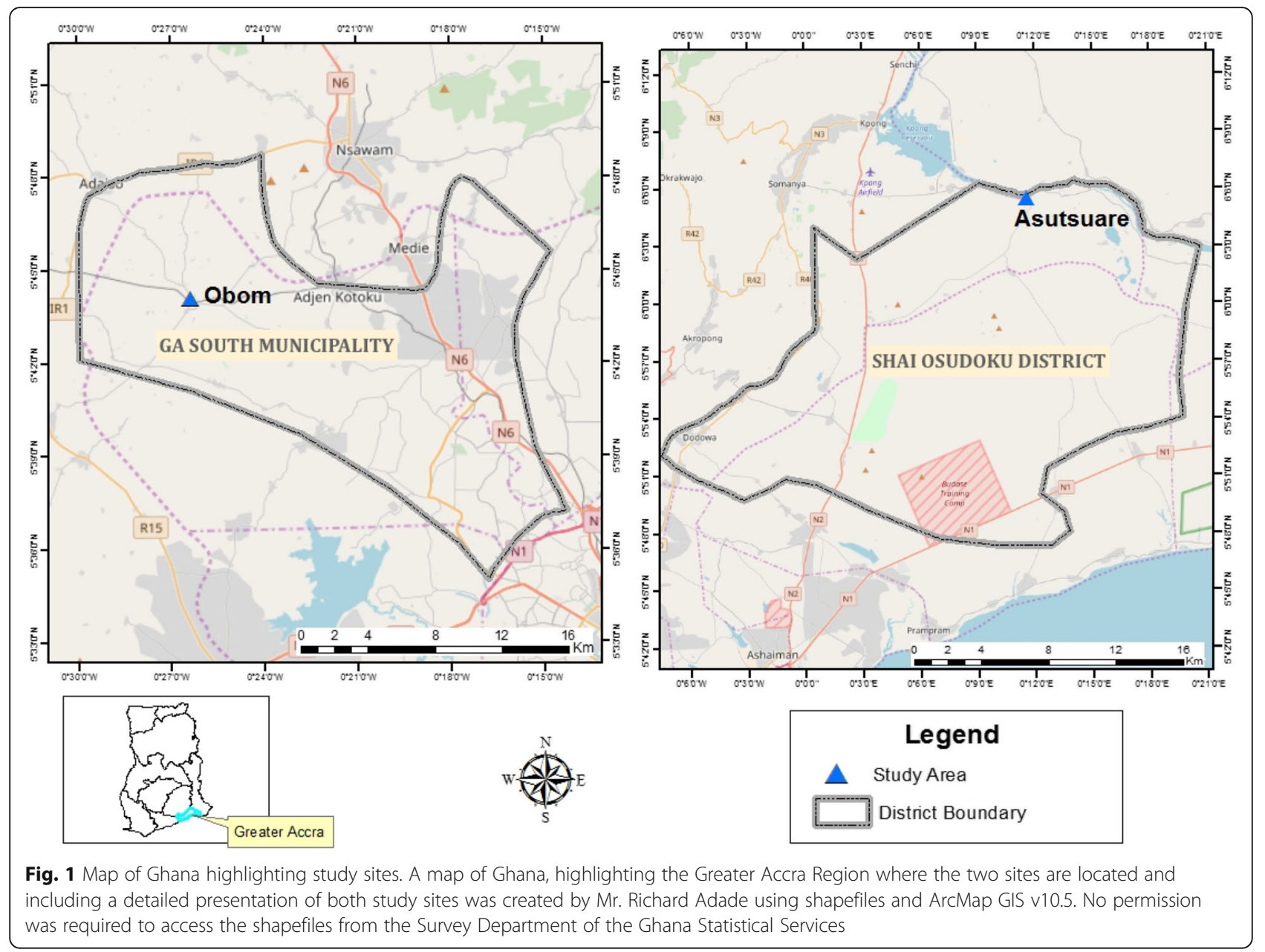

smears were dried, fixed in 100\% methanol and then stained with $10 \%$ Giemsa after the methanol had evaporated. Thick blood smears were air-dried and stained with $10 \%$ Giemsa. The thick and thin smears were observed under an $\times 100$ oil immersion objective by two independent microscopists. The thin smears were used to identify the infecting Plasmodium species [38].

\section{Enzyme linked immunosorbent assay (ELISA)}

Lactococcus lactis produced EBA175-RIII-V [39] was used in an indirect ELISA to measure total IgG and IgG subclass (IgG1, IgG2, IgG3 and IgG4) antibody responses in plasma from the study participants using a protocol similar to that previously reported by Acquah, F et al [39] for IgG and a modification of Ismail, HA et al [21] for the IgG subclasses. Briefly, $1 \mathrm{ng}$ of purified antigen, EBA175-RIII-V in phosphate buffered saline (PBS, pH 7.4) was coated $100 \mu \mathrm{l} /$ well onto NUNC MaxiSorp $^{\text {TM }}$ ELISA plates (Thermo Scientific, UK) overnight at $4{ }^{\circ} \mathrm{C}$. Plates were blocked with $150 \mu \mathrm{l} /$ well of $3 \%(w / v)$ skimmed milk powder (Marvel, UK) in PBS/T after four washes using PBS supplemented with $0.05 \%$ Tween 20
(PBS/T). Duplicate wells of the plates were then incubated with $100 \mu \mathrm{l}$ of plasma diluted 200-fold and a reference standard, purified human polyclonal IgG $[40,41]$ (BP055, The Binding Site, UK) at a starting concentration of $1000 \mathrm{ng} / \mu \mathrm{l}$ and serially diluted 3-fold in duplicate wells was used as a standard calibrator.

Plates were incubated for an hour at room temperature and then washed four times with $\mathrm{PBS} / \mathrm{T}$. The plates were subsequently incubated with $50 \mu \mathrm{l}$ of goat anti-human IgG-HRP (Invitrogen, USA) secondary antibodies for IgG.

For the IgG subclass ELISA, the plates were processed as for the IgG above, however the plates were incubated with $100 \mu \mathrm{l}$ of plasma diluted $1: 50$ at $37^{\circ} \mathrm{C}$ for $1 \mathrm{~h}$ and after washing, incubated with $50 \mu \mathrm{l}$ of goat anti-human IgG1-HRP (The Binding Site, UK) and goat anti-human IgG3-HRP (The Binding Site, UK) secondary antibodies. A positive control sample was obtained by pooling a number of samples that had previously identified as containing high concentrations of EBA175-RIII-V [42]. This positive control sample was serially diluted to prepare the standard curve) at a starting concentration of 1:10 and serially diluted 2 fold. Sera from adults living in the 
USA who have never been exposed to malaria (malaria naïve sera) and confirmed as having extremely low concentrations of EBA175RIII-V antibody levels were used as negative control samples. A positive and some negative control samples were used on each ELISA plate.

All plates were developed by adding $50 \mu \mathrm{l} /$ well of $3,3^{\prime}, 5,5^{\prime}$-tetramethylbenzidine (TMB) solution for 15 min for total IgG or $20 \mathrm{~min}$ for the IgG subclasses and then stopped with $2 \mathrm{M} \mathrm{H}_{2} \mathrm{SO}_{4}$. Fluorescence was measured immediately after stopping the reactions using excitation wavelength of $450 \mathrm{~nm}$.

\section{IgG avidity ELISA}

A procedure similar to the total IgG ELISA described above was used, however four replica wells were incubated with each appropriately diluted plasma sample for an hour, after which $100 \mu \mathrm{l} /$ well of $2.4 \mathrm{M}$ sodium thiocyanate (NaSCN; Sigma-Aldrich, UK) was added for an extra $10 \mathrm{~min}$ incubation [42-44] prior to the wash and subsequent addition of $50 \mu \mathrm{l} /$ well of goat anti-human IgG-HRP (Invitrogen, USA).

\section{Data analysis}

A thick blood smear was classified as negative for Plasmodium parasites if no infected erythrocytes were observed after counting 200 WBCs by both microscopists. In instances where disparities were observed in identifying the presence of Plasmodium infected erythrocytes, the smear was given to a third microscopist to confirm the presence or absence of Plasmodium infected erythrocytes. Once a thick smear was identified as containing Plasmodium infected erythrocytes, the corresponding thin smear was inspected to determine the Plasmodium species present in the sample.

Demographic data was entered into excel and column statistics determined using GraphPad Prism v5 (GraphPad software, USA).

Optical density (OD) results from the ELISA plate reader were converted into concentrations using the four-parameter curve-fitting program known as ADAMSEL (Ed Remarque, BPRC) and the data analyzed using GraphPad Prism v5 (GraphPad software, USA). The correlation between age and EBA175RIII-V antibody (IgG, IgM, IgG1 and IgG3) concentrations were performed using Spearman non-parametric correlation matrix and Mann Whitney $\mathrm{U}$ tests used to determine the differences in similar antibody responses between the two sites.

Seropositivity was defined as antibody concentration higher than the average antibody concentration of the negative control samples (naïve serum) plus two standard deviations.

Relative antibody avidity was determined as the ratio of the mean IgG concentration of the $\mathrm{SCN}^{-}$-treated sample to the mean IgG concentration of the untreated sample multiplied by 100 . (Avidity index $=$ [antibodies following $\mathrm{NaSCN}$ treatment/ antibodies without $\mathrm{NaSCN}$ treatment] $\times 100$ ).

Participants were stratified into three age groups, $\leq 10$ (ten and below 10), 11-14 and $\geq 15$ (fifteen and above) for some of the analysis. Data from seven participants from Asutsuare were excluded in age stratified analysis because their ages were not recorded. Statistical significance was defined as $P$ value $\leq 0.05$ unless otherwise stated.

\section{Results}

The age range for the 161 study participants from Obom was 6 to 70 years, while that of the 169 participants from Asutsuare was 2 and 75 years (Table 1). Asymptomatic P. falciparum parasite carriage, as determined by light microscopy, was higher in Obom (57 of the 160 participants or 35.6\%) compared to Asutsuare (6 of the 169 participants, representing or $3.5 \%)$. There was thus a 10 -fold difference in parasite carriage between the two study communities (Table 1). Bed net ownership was low in both communities, only 11 and 2 participants in Obom and Asutsuare respectively claimed to own bed nets.

\section{Seroprevalence of antibodies against recombinant EBA175RIII- $\mathrm{V}_{\mathrm{LI}}$ antigen}

The cutoff values used to calculate seroprevalence was 2581, 1773, 580 and 1198 AU for IgG1, IgG2, IgG3 and IgG4 respectively and $2137 \mathrm{ng} / \mathrm{ml}$ for IgG. The seroprevalence of IgG and IgG subclasses to EBA175RIII- $\mathrm{V}_{\mathrm{Ll}}$ of participants from Obom (IgG, 85.6\%; IgG1, 90.6\%; IgG2, 51.3\%; IgG3, 91.3\% and IgG4, 25.0\%) was significantly higher $(P<0.05$, Mann Whitney test) than participants from Asutsuare (IgG, 58.0\%; IgG1, 34.9\%; IgG2, $5.9 \%$; IgG3, 31.4\% and IgG4, 16.0\%). Seropositivity to the cytophilic IgG subclasses, IgG1 and IgG3 against EBA175 RIII- $\mathrm{V}_{\mathrm{Ll}}$ in both Obom and Asutsuare was higher than seropositivity to IgG2 and IgG4.

\section{Concentration of antibodies against recombinant EBA175RIII- $\mathrm{V}_{\mathrm{LI}}$ antigen}

Although 161 and 169 participant samples were used for all the different ELISAs, some samples had values, which

Table 1 Characteristics of study participants

\begin{tabular}{llll}
\hline & $N$ & $\%$ Asymptomatic infections & Median age (years) \\
\hline Obom & 161 & 35.6 & $15(6-70)$ \\
Asutsuare & 168 & 3.5 & $16(2-75)$ \\
\hline
\end{tabular}

$N$ total number of volunteers enrolled, \% Asymptomatic is the \% of people that tested positive for $P$. falciparum by microscopy. Median values reported with minimum and maximum age values 
were classified as 'Low' by the plate reader, meaning their value was similar to the blank sample and were not assigned a value. Those samples were not included in the analysis and subsequently resulted in variations in the final total number of samples, $\mathrm{N}$ used in the analysis.

The median antibody concentrations for both IgG and all the four IgG subclasses (IgG1, IgG2, IgG3 and IgG4) measured in participants from Obom were significantly higher than those recorded for from participants from Asutsuare $(p<0.0001$, Mann Whitney test for each) (Figs. 2a and 3a-d). The cytophilic IgG1 and IgG3 antibody responses measured in both sites were higher than the antibody concentrations of IgG2 and IgG4 (Table 2).

Levels of IgG, IgG1, IgG2 and IgG3 antibody responses significantly correlated with age in Obom (Spearman rho: $0.2244,0.2677,0.2210$ and 0.1724 respectively; $P<0.05$ in all cases). However, there was no correlation between the levels of IgG4 antibody responses in Obom or any of the antibody responses measured in samples from Asutsuare with age (Fig. 3).

\section{Antibody avidity}

The relative avidity index of IgG responses measured in participants from Obom and Asutuare both significantly correlated negatively with age, (Spearman $r=-0.2338, p<0.0072$ in Obom; Spearman $r=-0.1824, p=0.0394$ in Asutsuare). Although the antibody concentrations measured in volunteers from Asutsuare were significantly lower than those measured in volunteers from Obom (Fig. 2a), the relative avidities of IgG antibodies against EBA175RIII-V were higher in the volunteers from Asutsuare than from Obom (Fig. 2b). Antibody avidity index (RAI) of IgG for participants from Obom who were 10 years old and below were significantly

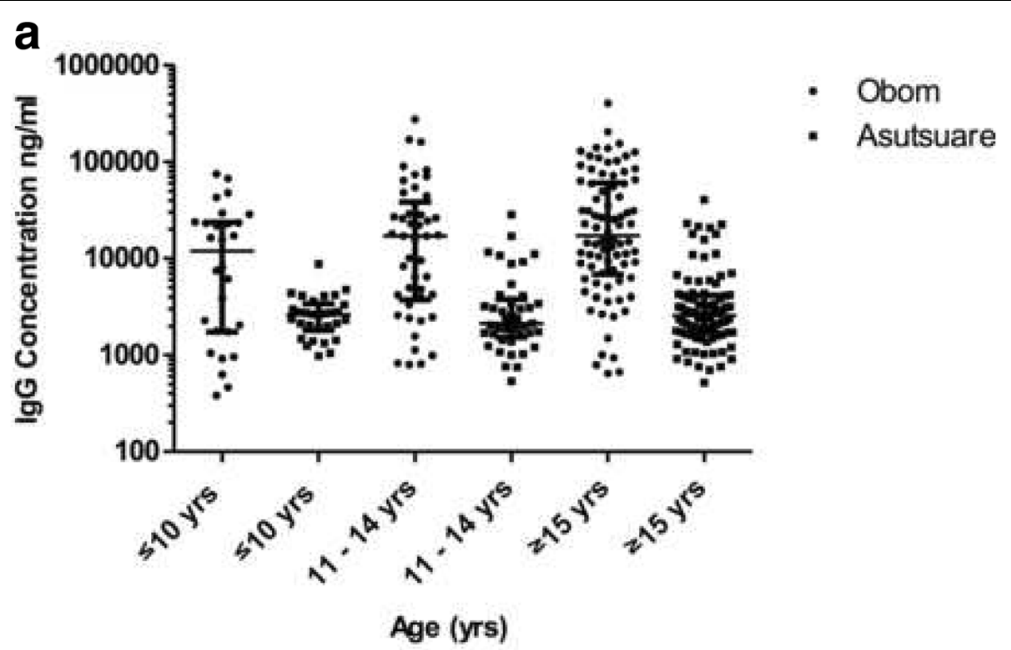

b

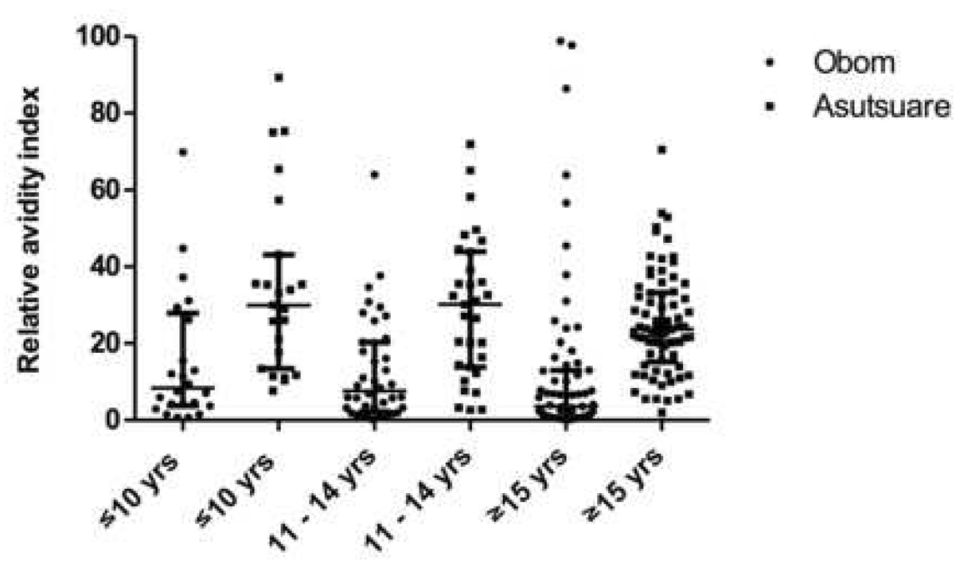

Age (yrs)

Fig. 2 Age stratified IgG concentrations and avidity. Participants in Obom (black circles) and Asutsuare (black squares) were stratified into three age groups, $\leq 10,11-14$ and $\leq 15$ years. The concentrations (a) and relative avidities (b) of naturally induced IgG antibodies against EBA175RIII-V antigen in plasma samples obtained from whole blood collected in June 2016 was measured using ELISA as described in the methods section. The graphs represent the median concentrations with the interquartile range as the error bars 


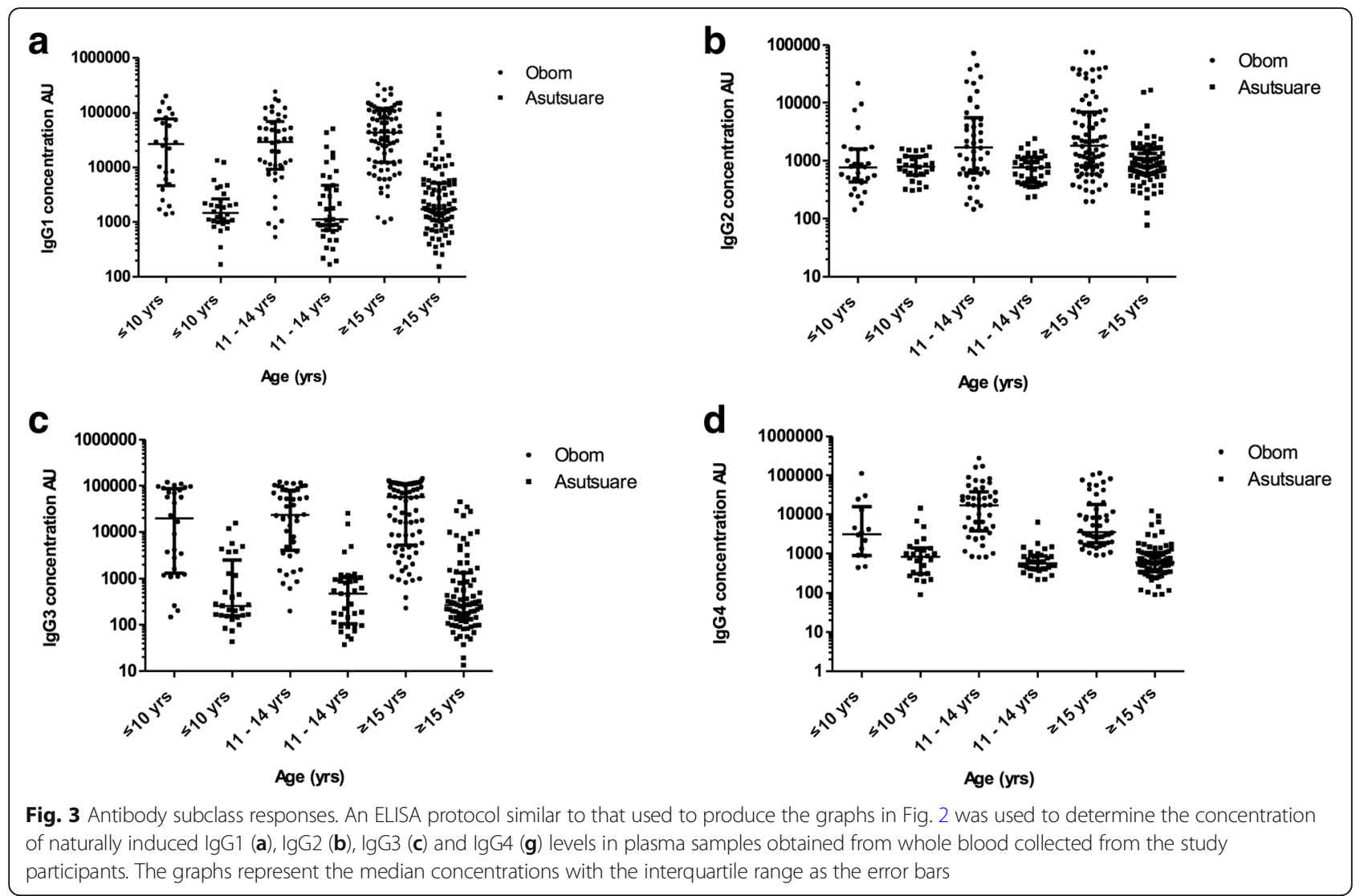

lower ( $p<0.05$, Dunn's multiple comparison test) than the RAI for all three categories (10 years and below, between 11 and 14 years and those 15 years and above) of participants in Asutsuare (Additional file 1). The RAI of IgG for participants from Obomaged 10 years and below was significantly higher $(p<0.001$, Dunn's multiple comparison

Table 2 lgG and IgG subclass antibody concentrations

\begin{tabular}{llllll}
\hline & & $\mathrm{N}$ & Min & Median & Max \\
\hline lgG & Obom & 156 & 380.5 & 16,006 & 403,567 \\
(ng/ml) & Asutsuare & 168 & 518.8 & 2411 & 40,686 \\
lgG1 & Obom & 153 & 526.8 & 33,041 & 331,686 \\
$(\mathrm{AU})$ & Asutsuare & 165 & 154.2 & 1660 & 93,998 \\
$\operatorname{lgG} 2$ & Obom & 158 & 142.2 & 1409 & 75,188 \\
(AU) & Asutsuare & 162 & 76.67 & 770 & 16,397 \\
lgG3 & Obom & 156 & 146.8 & 40,009 & 141,652 \\
$(\mathrm{AU})$ & Asutsuare & 156 & 13.4 & 270.7 & 45,058 \\
lgG4 & Obom & 88 & 76.98 & 3152 & 113,147 \\
$(\mathrm{AU})$ & Asutsuare & 143 & 89.89 & 605.8 & 14,617 \\
\hline
\end{tabular}

$N$ total number of samples used in the analysis, Min minimum concentration, Max maximum concentration. Total lgG was measured in $\mathrm{ng} / \mathrm{ml}$, whilst the lgG subclasses were measured in arbitrary units (AU) test) than participants aged between 11 and 14 years as well as those 15 years and above (Additional file 1).

\section{Discussion}

Rabbit serum containing polyclonal antibodies against Region III-V of EBA175 have been found to directly inhibit P. falciparum merozoite invasion [10]. Naturally induced antibodies against Region III-V of EBA175 have also been suggested to be indicative of strong protection from symptomatic malaria [45], however the role antibodies against EBA175RIII-V play in asymptomatic malaria has not been fully evaluated. Data from the assessment of the magnitude and avidity of antibody responses to this antigen across different age groups will potentially be relevant for the interpretation of natural and vaccine induced immune responses to this antigen.

In order to determine possible differences in natural antibody responses to Region III-V of EBA175, a cross sectional survey was carried out in Obom, which has been reported to be a high parasite prevalence community [46] and in Asutsuare, where parasite prevalence and malaria transmission intensity is known to be very low [35]. The study enrolled a range of children and adults to determine possible differences in age related 
antibody responses. This study confirmed the existence of very low $P$. falciparum parasite prevalence in Asutsuare (Table 1) as has previously been reported [35]. The number of asymptomatic individuals in Asutsuare however may be higher than the $3.5 \%$ if Plasmodium parasites were detected by molecular methods. Especially as a higher number of submicroscopic parasite infections are detected in asymptomatic individuals due to the increased sensitivity of the detection technique [47]. Bed net ownership was generally low in both communities. Ownership in Obom was higher than in Asutsuare, most likely because residents of Asutsuare encounter very low frequencies of malaria that they no longer think it is important to implement personal malaria control interventions relative to inhabitants of Obom, where malaria transmission is high.

Although only $3.5 \%$ of the participants from Asutsuare had microscopic densities of parasites, almost $60 \%$ of them were seropositive for anti-EBA175RIII-V antibodies. Similarly, although only about $35 \%$ of the participants from Obom were identified by microscopy as harboring P. falciparum parasites, over $80 \%$ had IgG antibodies against EBA175RIII-V. These collectively suggest the possible presence of parasites at densities below the detection limit of microscopy in some of the participants or that some of the participants had just recently cleared a $P$. falciparum infection, as antibodies against EBA175 have been suggested to be relatively short-lived [21].

The significantly higher IgG responses recorded in Obom than in Asutsuare (Fig. 2a) is indicative of the possible requirement of an active infection to induce antibodies against EBA175RIII-V as has been previously suggested, especially as these antibodies are relatively short-lived [21]. IgG subclass responses in both sites were predominantly cytophilic (IgG1 and IgG3) (Fig. 3), which supports a number of previous reports $[9,21,48$, 49]. However responses to IgG2 and IgG4 existed, although at much lower quantities and has been suggested to be due to the much shorter half-lives of $\operatorname{IgG} 2$ and IgG4 compared to IgG1 and IgG3 [21]. IgG subclass antibody levels were significantly higher in Obom than in Asutsuare, which was not surprising as total IgG levels were also significantly higher in Obom than in Asutsuare.

In Obom, the high transmission setting, IgG, IgG1 and IgG3 responses to EBA175RIII-V positively correlated with age (Figs. 2a, 3a\&c). This supports data from a previous study conducted in a high transmission setting in Nigeria [21] and that of another study in highly asymptomatic children from a moderately seasonal setting Papua New Guinea [9]. High IgG1 and IgG3 responses for other merozoite antigens such as MSP1 [50] and MSP2 [51] have also been documented. A previous study did not find any correlation between IgG2 and IgG4 responses against EBA175 and age [21], however in this study, IgG2 responses correlated positively (Fig. $3 \mathrm{~b}$ ) with age in responses measured in the high transmission setting, Obom. The lack of age associated antibody responses in Asutsuare (Figs. 2a \& 3) may be due to the very low prevalence of parasites observed in the community (Table 1) as parasite exposure has been found to be necessary for mounting immune responses against malaria antigens.

The relative antibody avidities measured in the participants from Asutsuare, the low transmission setting were significantly higher than those measured in Obom (Fig. 2b). A similar observation has been reported for antibody responses to this same antigen conducted in children living in the same high transmission setting and a different low transmission setting in Ghana [42] as well as for antibody responses to a different merozoite antigen, $\mathrm{MSP}_{19}$ [34] and could be due to the presence of fewer and less diverse parasite clones circulating in low transmission zones [52]. Although high parasite diversity and frequency of infection is anticipated in high transmission settings, the diversity of RIII-V of EBA175 was recently suggested to be relatively similar in parasites circulating in Obom (the high transmission setting) and Abura [42], a community with low parasite transmission intensity, similar to Asutsuare. Generally, an increase in exposure to diverse parasites strains/isolates will result in heterologous exposure, which could lead to reduced affinity maturation and the production of antibodies with lower avidities as measured in antibody responses in Obom. A recent report on the avidity of naturally induced antibodies against EBA175RIII-V in children living in southern Ghana similarly reported reduced avidity of antibodies from children living in the high transmission setting compared to the low transmission setting [42].

The likely short longevity of naturally induced antibodies against EBA175RIII-V is contrary to the dynamics of antibodies against MSP1- 19 , which have been found to persist for several years after the clearance of $P$. falciparum parasites $[53,54]$ and thus may be a suitable candidate to use as a serological marker to monitor changes in malaria transmission intensity.

\section{Conclusion}

People living in communities with limited exposure to $P$. falciparum parasites have low quantities of high avidity antibodies against EBA175RIII-V whilst people living in communities with high exposure to the parasites have high quantities of age dependent but low avidity antibodies against EBA175RIII-V. 


\section{Additional file}

Additional file 1: A tabular (a) and the corresponding column statistics (b) obtained from a One way ANOVA analysis (Prism v5) of the relative avidity of naturally induced antibodies against EBA175RIII-V in the age stratified $\leq 10,11-14$ and $\geq 15$ years participants from Obom and Asutsuare. (DOCX $50 \mathrm{~kb})$

\section{Abbreviations}

ACD: Acid citrate dextrose; AU: Antibody unit; DBS: Dried blood spot; EBA 175: Erythrocyte binding antigen 175; ELISA: Enzyme linked immunosorbent assay; IgG: Immunoglobulin; OD: Optical density

\section{Acknowledgements}

The authors are grateful to all the study participants and to Mr. Abdul Haruna and Mr. Eric Kyei-Baffour both of the University of Ghana for help with reading the thick and thin blood smears. We also thank Mr. Richard Adade, GIS \& Remote Sensing Unit, Department of Fisheries and Aquatic Science, Center for Coastal Management, University of Cape Coast, Cape Coast, Ghana for creating the map of the study sites.

\section{Funding}

This project was supported in part by the Ghana government Book and Research allowance to LEA and the Bill and Melinda Gates foundation through the NMIMR Postdoctoral Fellowship awarded to AL. "The funders had no role in study design, data collection and analysis, decision to publish, or preparation of the manuscript".

\section{Availability of data and materials}

The datasets used and/or analysed during the current study available from the corresponding author on reasonable request.'

\section{Authors' contributions}

'LEA, BG and AL designed the study; LEA, HBA, BG and KAK wrote the manuscript and performed the statistical analysis; LEA and AL provided reagents, $\mathrm{AL}$ and $\mathrm{KA}-\mathrm{M}$ collected the samples; $\mathrm{HA}$ performed the experiments. All authors read and approved the final manuscript.'

\section{Ethics approval and consent to participate}

Ethical approval for the study was obtained from the Institutional Review Board of the Noguchi Memorial Institute for Medical Research (Study number 089/14-15). Written informed consent, assent and parental consent were obtained for all participants recruited into the study.

\section{Consent for publication}

NA

\section{Competing interests}

The authors declare that they have no competing interests.

\section{Publisher's Note}

Springer Nature remains neutral with regard to jurisdictional claims in published maps and institutional affiliations.

\section{Author details}

${ }^{1}$ Noguchi Memorial Institute for Medical Research, University of Ghana, Accra, Ghana. ${ }^{2}$ Present address: University Cheikh Anta DIOP, Dakar, Senegal.

\section{Received: 28 February 2018 Accepted: 8 November 2018}

Published online: 19 November 2018

\section{References}

1. Okenu DM, Riley EM, Bickle QD, Agomo PU, Barbosa A, Daugherty JR, Lanar $\mathrm{DE}$, Conway DJ. Analysis of human antibodies to erythrocyte binding antigen 175 of Plasmodium falciparum. Infect Immun. 2000;68(10):5559-66.

2. Sim B. EBA-175: an erythrocyte-binding ligand of Plasmodium falciparum. Parasitol Today. 1995;11(6):213-7.

3. Turner L, Wang CW, Lavstsen T, Mwakalinga SB, Sauerwein RW, Hermsen CC, Theander TG. Antibodies against PfEMP1, RIFIN, MSP3 and GLURP are acquired during controlled Plasmodium falciparum malaria infections in naive volunteers. PLoS One. 2011;6(12):e29025.

4. Wipasa J, Elliott $\mathrm{S}, \mathrm{Xu}$ H, Good MF. Immunity to asexual blood stage malaria and vaccine approaches. Immunol Cell Biol. 2002;80(5):401-14.

5. Beeson JG, Osier FH, Engwerda CR. Recent insights into humoral and cellular immune responses against malaria. Trends Parasitol. 2008;24(12): 578-84

6. Cohen S, Mc Gl, Carrington S. Gamma-globulin and acquired immunity to human malaria. Nature. 1961;192:733-7.

7. Sabchareon A, Burnouf T, Ouattara D, Attanath P, Bouharoun-Tayoun $\mathrm{H}_{\text {, }}$ Chantavanich P, Foucault C, Chongsuphajaisiddhi T, Druilhe P. Parasitologic and clinical human response to immunoglobulin administration in falciparum malaria. Am J Trop Med Hyg. 1991;45(3):297-308.

8. Brown GV, Anders RF, Mitchell GF, Heywood PF. Target antigens of purified human immunoglobulins which inhibit growth of Plasmodium falciparum in vitro. Nature. 1982;297(5867):591-3.

9. Richards JS, Stanisic DI, Fowkes FJ, Tavul L, Dabod E, Thompson JK, Kumar S, Chitnis CE, Narum DL, Michon P, et al. Association between naturally acquired antibodies to erythrocyte-binding antigens of Plasmodium falciparum and protection from malaria and high-density parasitemia. Clin Infect Dis. 2010:51(8):e50-60.

10. Healer J, Thompson JK, Riglar DT, Wilson DW, Chiu YH, Miura K, Chen L, Hodder AN, Long CA, Hansen DS, et al. Vaccination with conserved regions of erythrocyte-binding antigens induces neutralizing antibodies against multiple strains of Plasmodium falciparum. PLoS One. 2013;8(9):e72504.

11. Langhorne J, Ndungu FM, Sponaas AM, Marsh K. Immunity to malaria: more questions than answers. Nat Immunol. 2008;9(7):725-32.

12. Kinyanjui SM, Conway DJ, Lanar DE, Marsh K. IgG antibody responses to Plasmodium falciparum merozoite antigens in Kenyan children have a short half-life. Malar J. 2007:6:82.

13. Kusi KA, Bosomprah S, Kyei-Baafour E, Dickson EK, Tornyigah B, Angov E, Dutta S, Dodoo D, Sedegah M, Koram KA. Seroprevalence of antibodies against Plasmodium falciparum Sporozoite antigens as predictive disease transmission markers in an area of Ghana with seasonal malaria transmission. PLoS One. 2016;11(11):e0167175.

14. Kusi KA, Bosomprah S, Dodoo D, Kyei-Baafour E, Dickson EK, Mensah D, Angov E, Dutta S, Sedegah M, Koram KA. Anti-sporozoite antibodies as alternative markers for malaria transmission intensity estimation. Malar J. 2014;13:103.

15. Jakobsen PH, Kurtzhals JA, Riley EM, Hviid L, Theander TG, Morris-Jones S, Jensen JB, Bayoumi RA, Ridley RG, Greenwood BM. Antibody responses to Rhoptry-associated Protein-1 (RAP-1) of Plasmodium falciparum parasites in humans from areas of different malaria endemicity. Parasite Immunol. 1997; 19(9):387-93.

16. Al-Yaman F, Genton B, Anders RF, Falk M, Triglia T, Lewis D, Hii J, Beck HP, Alpers MP. Relationship between humoral response to Plasmodium falciparum merozoite surface antigen-2 and malaria morbidity in a highly endemic area of Papua New Guinea. Am J Trop Med Hyg. 1994;51(5):593-602.

17. Soares IS, da Cunha MG, Silva MN, Souza JM, Del Portillo HA, Rodrigues MM Longevity of naturally acquired antibody responses to the $\mathrm{N}$ - and Cterminal regions of Plasmodium vivax merozoite surface protein 1. Am J Trop Med Hyg. 1999:60(3):357-63.

18. Wipasa J, Suphavilai C, Okell LC, Cook J, Corran PH, Thaikla K, Liewsaree W, Riley EM, Hafalla JC. Long-lived antibody and B cell memory responses to the human malaria parasites, Plasmodium falciparum and Plasmodium vivax. PLoS Pathog. 2010;6(2):e1000770.

19. Fruh K, Doumbo O, Muller HM, Koita O, McBride J, Crisanti A, Toure Y, Bujard $\mathrm{H}$. Human antibody response to the major merozoite surface antigen of Plasmodium falciparum is strain specific and short-lived. Infect Immun. 1991;59(4):1319-24.

20. Cavanagh DR, Elhassan IM, Roper C, Robinson VJ, Giha H, Holder AA, Hviid L, Theander TG, Arnot DE, McBride JS. A longitudinal study of type-specific antibody responses to Plasmodium falciparum merozoite surface protein-1 in an area of unstable malaria in Sudan. J Immunol. 1998;161(1):347-59.

21. Ahmed Ismail $H$, Tijani MK, Langer C, Reiling L, White MT, Beeson JG, Wahlgren M, Nwuba R, Persson KE. Subclass responses and their half-lives for antibodies against EBA175 and PfRh2 in naturally acquired immunity against Plasmodium falciparum malaria. Malar J. 2014;13:425.

22. Weaver R, Reiling L, Feng G, Drew DR, Mueller I, Siba PM, Tsuboi T, Richards JS, Fowkes FJ, Beeson JG. The association between naturally 
acquired lgG subclass specific antibodies to the PfRH5 invasion complex and protection from Plasmodium falciparum malaria. Sci Rep. 2016;6:33094.

23. Richards JS, Arumugam TU, Reiling L, Healer J, Hodder AN, Fowkes FJ, Cross $\mathrm{N}$, Langer $\mathrm{C}$, Takeo S, Uboldi AD, et al. Identification and prioritization of merozoite antigens as targets of protective human immunity to Plasmodium falciparum malaria for vaccine and biomarker development. J Immunol. 2013;191(2):795-809.

24. Perciani CT, Peixoto PS, Dias WO, Kubrusly FS, Tanizaki MM. Improved method to calculate the antibody avidity index. J Clin Lab Anal. 2007; 21(3):201-6.

25. Tutterrow YL, Salanti A, Avril M, Smith JD, Pagano IS, Ako S, Fogako J, Leke RG, Taylor DW. High avidity antibodies to full-length VAR2CSA correlate with absence of placental malaria. PLoS One. 2012;7(6):e40049.

26. Nogaro SI, Hafalla JC, Walther B, Remarque EJ, Tetteh KK, Conway DJ, Riley EM, Walther M. The breadth, but not the magnitude, of circulating memory $B$ cell responses to $P$. falciparum increases with age/exposure in an area of low transmission. PLoS One. 2011:6(10):e25582.

27. Groux H, Gysin J. Opsonization as an effector mechanism in human protection against asexual blood stages of Plasmodium falciparum: functional role of IgG subclasses. Res Immunol. 1990;141(6):529-42.

28. Hill DL, Eriksson EM, Li Wai Suen CS, Chiu CY, Ryg-Cornejo V, Robinson LJ, Siba PM, Mueller I, Hansen DS, Schofield L. Opsonising antibodies to $P$. falciparum merozoites associated with immunity to clinical malaria. PLoS One. 2013;8(9):e74627

29. Ferreira MU, Kimura EA, De Souza JM, Katzin AM. The isotype composition and avidity of naturally acquired anti-Plasmodium falciparum antibodies: differential patterns in clinically immune Africans and Amazonian patients. Am J Trop Med Hyg. 1996;55(3):315-23.

30. Leoratti FM, Durlacher RR, Lacerda MV, Alecrim MG, Ferreira AW, Sanchez MC, Moraes SL. Pattern of humoral immune response to Plasmodium falciparum blood stages in individuals presenting different clinical expressions of malaria. Malar J. 2008;7:186.

31. Reddy SB, Anders RF, Beeson JG, Farnert A, Kironde F, Berenzon SK, Wahlgren M, Linse S, Persson KE. High affinity antibodies to Plasmodium falciparum merozoite antigens are associated with protection from malaria. PLoS One. 2012;7(2):e32242.

32. Cadman ET, Abdallah AY, Voisine C, Sponaas AM, Corran P, Lamb T, Brown $D$, Ndungu $F$, Langhorne J. Alterations of splenic architecture in malaria are induced independently of toll-like receptors 2, 4, and 9 or MyD88 and may affect antibody affinity. Infect Immun. 2008;76(9):3924-31.

33. Anders RF. Multiple cross-reactivities amongst antigens of Plasmodium falciparum impair the development of protective immunity against malaria. Parasite Immunol. 1986;8(6):529-39.

34. Ssewanyana I, Arinaitwe E, Nankabirwa Jl, Yeka A, Sullivan R, Kamya MR, Rosenthal PJ, Dorsey G, Mayanja-Kizza H, Drakeley C, et al. Avidity of antimalarial antibodies inversely related to transmission intensity at three sites in Uganda. Malar J. 2017;16(1):67.

35. Dadzie SK, Aboagye-Antwi F, Kyerematen R, Ononye NC. Characterization of malaria transmission and insecticide susceptibility status of Anopheles gambiae Sensu Lato Gilles (Diptera: Culicidae) in Shai-Osudoku District of southern Ghana. Ghana: University of Ghana; 2015.

36. Donovan C, Siadat B, Frimpong J. Seasonal and socio-economic variations in clinical and self-reported malaria in Accra, Ghana: evidence from facility data and a community survey. Ghana Med J. 2012;46(2):85-94.

37. WHO. Giemsa Staining of Malaria Blood Films. In: malaria microscopy standard operating procedure - MM-SOP-07A; 2016.

38. W.H.O. Malaria parasite counting. In: Malaria Microscopy Standard Operating Procedure - MM-SOP-09; 2016.

39. Acquah FK, Obboh EK, Asare K, Boampong JN, Nuvor SV, Singh SK, Theisen M, Williamson KC, Amoah LE. Antibody responses to two new Lactococcus lactis-produced recombinant Pfs48/45 and Pfs230 proteins increase with age in malaria patients living in the central region of Ghana. Malar J. 2017; 16(1):306.

40. Dodoo D, Aikins A, Kusi KA, Lamptey H, Remarque E, Milligan P, Bosomprah $S$, Chilengi $R$, Osei YD, Akanmori BD, et al. Cohort study of the association of antibody levels to AMA1, MSP119, MSP3 and GLURP with protection from clinical malaria in Ghanaian children. Malar J. 2008;7:142.

41. Jepsen MP, Roser D, Christiansen M, Olesen Larsen S, Cavanagh DR Dhanasarnsombut K, Bygbjerg I, Dodoo D, Remarque EJ, Dziegiel M, et al. Development and evaluation of a multiplex screening assay for Plasmodium falciparum exposure. J Immunol Methods. 2012;384(1-2):62-70.
42. Abagna HB, Acquah FK, Okonu R, Aryee NA, Theisen M, Amoah LE. Assessment of the quality and quantity of naturally induced antibody responses to EBA175RIII-V in Ghanaian children living in two communities with varying malaria transmission patterns. Malar J. 2018;17(1):14.

43. Wilson KM, Di Camillo C, Doughty L, Dax EM. Humoral immune response to primary rubella virus infection. Clin Vaccine Immunol. 2006;13(3):380-6.

44. Ibison F, Olotu A, Muema DM, Mwacharo J, Ohuma E, Kimani D, Marsh K, Bejon P, Ndungu FM. Lack of avidity maturation of merozoite antigenspecific antibodies with increasing exposure to Plasmodium falciparum amongst children and adults exposed to endemic malaria in Kenya. PLoS One. 2012;7(12):e52939.

45. Chiu CY, White MT, Healer J, Thompson JK, Siba PM, Mueller I, Cowman AF, Hansen DS. Different regions of Plasmodium falciparum erythrocyte-binding antigen 175 induce antibody responses to infection of varied efficacy. J Infect Dis. 2016;214(1):96-104.

46. Amoah LE, Opong A, Ayanful-Torgby R, Abankwa J, Acquah FK. Prevalence of G6PD deficiency and Plasmodium falciparum parasites in asymptomatic school children living in southern Ghana. Malar J. 2016;15(1):388.

47. Lo E, Zhou G, Oo W, Afrane Y, Githeko A, Yan G. Low parasitemia in submicroscopic infections significantly impacts malaria diagnostic sensitivity in the highlands of Western Kenya. PLoS One. 2015;10(3):e0121763.

48. Stanisic DI, Fowkes FJ, Koinari M, Javati S, Lin E, Kiniboro B, Richards JS, Robinson $L$, Schofield L, Kazura JW, et al. Acquisition of antibodies against Plasmodium falciparum merozoites and malaria immunity in young children and the influence of age, force of infection, and magnitude of response. Infect Immun. 2015:83(2):646-60.

49. Toure FS, Deloron P, Migot-Nabias F. Analysis of human antibodies to erythrocyte binding antigen 175 peptide 4 of Plasmodium falciparum. Clin Med Res. 2006;4(1):1-6.

50. Da Silveira LA, Dorta ML, Kimura EA, Katzin AM, Kawamoto F, Tanabe K, Ferreira MU. Allelic diversity and antibody recognition of Plasmodium falciparum merozoite surface protein 1 during hypoendemic malaria transmission in the Brazilian amazon region. Infect Immun. 1999;67(11): 5906-16.

51. Taylor RR, Smith DB, Robinson VJ, McBride JS, Riley EM. Human antibody response to Plasmodium falciparum merozoite surface protein 2 is serogroup specific and predominantly of the immunoglobulin G3 subclass. Infect Immun. 1995;63(11):4382-8

52. Adjah J, Fiadzoe B, Ayanful-Torgby R, Amoah LE. Seasonal variations in Plasmodium falciparum genetic diversity and multiplicity of infection in asymptomatic children living in southern Ghana. BMC Infect Dis. 2018; 18(1):432.

53. Drakeley CJ, Corran PH, Coleman PG, Tongren JE, McDonald SL, Carneiro I, Malima R, Lusingu J, Manjurano A, Nkya WM, et al. Estimating medium- and long-term trends in malaria transmission by using serological markers of malaria exposure. Proc Natl Acad Sci U S A. 2005;102(14):5108-13.

54. Zoghi S, Mehrizi AA, Raeisi A, Haghdoost AA, Turki H, Safari R, Kahanali AA, Zakeri S. Survey for asymptomatic malaria cases in low transmission settings of Iran under elimination programme. Malar J. 2012;11:126.

Ready to submit your research? Choose BMC and benefit from

- fast, convenient online submission

- thorough peer review by experienced researchers in your field

- rapid publication on acceptance

- support for research data, including large and complex data types

- gold Open Access which fosters wider collaboration and increased citations

- maximum visibility for your research: over $100 \mathrm{M}$ website views per year

At $\mathrm{BMC}$, research is always in progress.

Learn more biomedcentral.com/submission 